\title{
Ukraine blev ude i kulden
}

\section{Vibeke Sperling}

\section{For fem år siden fulgte en folkeopstand i Ukraine mod kommunismens efterladenskaber. Men leder- ne af den Orange Revolution kastede sig ud i op- slidende magtkampe, unge udvandrede, appeller til Vesten blev i vidt omfang overhørt, og Rusland blander sig igen i valgkamp}

Da kommunismen faldt i Centraleuropa vakte det stor genklang i Ukraine, hvor nationalister og frihedsbevægelser allerede på det tidspunkt havde skabt et aktivt civilsamfund. Det manifesterede sig med massiv opbakning ved folkeafstemningen om ukrainsk selvstændighed, da Sovjetunionens dage var talte, og toppede med den Orange Revolution i 2004.

Da selvstændigheden kom, havde Ukraine en voksende befolkning, der toppede med 52,24 millioner i 1992. Så gik det ifølge Ukraines Statistik hastigt tilbage til lidt over 46 millioner i juli i år. Ifølge FN vil den ukrainske befolkning have mistet yderligere ti millioner i 2050, hvis udviklingen fortsætter. Den demografiske udvikling er i dag en af indikatorerne på landets ekstraordi- nært store økonomiske og sociale problemer. Og den forstærkes af, at unge og veluddannede søger ud i hastigt tempo og bliver derude.

"Drager stjernerne ud, mens tåberne bliver?", spurgte den ukrainske journalist Natalija Bugajova i avisen Kyiv Post i september i år. "Hvert år forlader tusindvis af de mest lovende unge Ukraine med intentionen om aldrig at vende tilbage. Det er intet under, at vi altid synes på kanten af insolvens", skrev Bugajova og videre:

"De, som er så heldige at bo i Kijev, får en god uddannelse og havner i et godt job kan møjsommeligt skaffe sig en acceptabel eksistens. Men Kijev er ikke Ukraine. Derude i provinsen, i landsbyer og på landet, er der hundredtusinder af unge, fremragende studerende, 
der spørger sig selv, om de skal blive eller rejse væk".

Bugajova henviser til den sovjetiske talemåde, der vist stammer fra Stalin: "En kok kan styre landet". Hun konkluderer, at det kan en kok så afgjort ikke. "Men her er vi så $\mathrm{i}$ Ukraine med kokke, der styrer. Vi sidder fast med vore tyve, spytslikkere og vores offermentalitet".

\section{Livligt civilsamfund}

Når de såkaldte farverevolutioner som Roserevolutionen i Georgien i 2003 og den Orange Revolution i Ukraine 2004 blev gennemført i netop disse to tidligere sovjetrepublikker, var det ikke fordi her var mest at gøre oprør imod under postkommunismen. Det var tværtimod fordi der i netop de to lande var størst ytrings- og handlefrihed for borgerne og derfor de mest aktive civilsamfund.

De var inspireret af vestlige naboer og ikke mindst af Polen, men endnu mere af det også forsinkede oprør i det tidligere Jugoslavien, da Slobodan Milosevic var den hensygnende jugoslaviske unions præsident. Det var den serbiske ungdomsbevægelse Otpor, som de ukrainske unge lod sig mest inspirere af, som tilfældet havde været blandt de georgiske unge året før.

I begge lande var der tale om det opgør med kommunismen, som kommunismens fald i Sovjetunionen ikke havde bragt. De tidligere kommunistiske ledere overlevede i nationalistiske klæder. Men da georgierne og ukrainerne i henholdsvis 2003 og 2004 blev frastjålet deres stemmer ved valg, blev det simpelthen for meget. På det tidspunkt gik det for alvor op for folk i begge lande, at de var blevet snydt for de politiske og økonomiske reformer, som de troede ville komme med Sovjetunionens sammenbrud.

Det er heller ikke noget tilfælde, at det netop er de to lande, som er på kant med den russiske ledelse. De folkelige opstande i Georgien og Ukraine skabte angst blandt Ruslands magthavere for, at turen ville komme til dem.

\section{Ligheder med Østeuropa}

Vejen til et udfoldet demokrati har vist sig længere end forventet, da verden fulgte de orange med fryd og forundring.

Ukrainsk demokrati har vist nogle fremskridt siden den Orange Revolution, hvor der var tilbøjelighed til at sammenligne transformationen med de centraleuropæiske tidligere østbloklandes i 1990'erne. Men Ukraine måtte få det sværere med at overvinde udfordringerne, fordi dets udgangspunkt og historiske arv var så forskellig. Der er en afgrund til forskel mellem de tidligere satellitstater og sovjetrepublikkerne, der var langt mere direkte styret af Moskva.

Desuden var Ukraine den sovjet- 
republik, der var tættest knyttet til Rusland gennem den fælles vugge: Kijev. Det giver stærke følelsesmæssige og kulturelle bånd også i dag, at både russerne og ukrainere ser deres historie som udsprunget i et middelalderligt kongedømme med centrum i Kijev.

Opgøret med kommunismen, som udeblev ved Sovjetunionens sammenbrud, betød, at Ukraine har haft mange skavanker at overvinde fra det første postkommunistiske årti. Det gør opbygningen af et demokratisk styre i dagens post-postkommunistiske periode ekstra vanskelig: skabelse af en post-Orange Revolution koalition, bekæmpelse af en bundløs korruption og ringe respekt for love og myndigheder. Dertil er kommet den globale økonomiske krise, som Ukraine står meget mere ubeskyttet overfor end landene, der er optaget i EU. Den Orange Revolution skaffede ukrainerne af med et dybt udemokratisk system, men udviklingen har vist, at det endnu kun er ved begyndelsen af en demokratiseringsproces.

Om Ukraines dårlige udgangspunkt skriver forfatteren Bohdan Harasymiw i sit gigantværk Post-Communist Ukraine: "I slutningen af 1991 havde Ukraine praktisk talt ingen af de territoriale attributter for anerkendelse som stat. Næsten ingen, når det gjaldt statens relationer til befolkningen og kun få, når det gjaldt dets administrative apparat. Det var, om noget, kun en quasi stat".
"Ukraine fik en dårlig start, fordi det ikke fulgte vejen af 'intense forhandlinger' i sin overgang til demokrati. Udfordrerne af den gamle orden var simpelthen forsvarere for det gamle, der poserede som dets udfordrere, og der fandt ingen forhandlinger sted, hverken intense eller mindre intense. Udfordringerne imod konsolidering af demokrati var dengang meget store, netop fordi ingen virkelig kæmpede for demokrati: det faldt ned i skødet på dem”.

En ny valgkamp har længe været uofficielt i gang op til præsidentvalget i januar, og folkelig apati blandt de tidligere så aktive orange og deres modstandere er et af de store problemer.

\section{Yngste præsidentkandidat}

Den yngste præsidentkandidat, Arsenij Jatseniuk, fortalte på et valgmøde i begyndelsen af september en anekdote fra en samtale med en vælger i provinsen:

"Hvordan er forholdene i dit amt?", spørger Jatseniuk. "De stinker", svarer vælgeren. "Hvordan er din borgmester?". "Han er dårlig". "Hvordan er regionsrådet?". "Det samme. Ingen henter skraldet. Her er ingen rindende vand. ZHEK (kommunekontoret) fungerer ikke, og bybusserne kører ikke". "Hvem stemte du på ved sidste valg (lokalvalg. red.)?" "Ivan Ivanovitj". "Hvem vil du stemme på ved næste valg?". "Ivan Ivanovitj”. 
Jatseniuks pointe med anekdoten var, at niveauet af politisk ansvarlighed i provinsen som i hovedstaden svarer til niveauet af folkelig apati.

Den 35-årige tidligere parlamentsformand, viceudenrigsminister og leder af Ukraines nationalbank sagde: "Jeg takker jer for at tro på mig, men lad os alle starte med først at tro på os selv".

En del vælgeraktivitet er der trods alt. Jatseniuk har støttet etableringen af græsrodsbevægelsen Den Alukrainske Front for Forandring, der nu har 600 kontorer rundt i landet. Den nye præsidents første opgave er at få folk til at arbejde, sagde præsidentkandidaten: “Æraen, hvor Ukraine som en postindustriel nation tjente penge uden at producere noget, er forbi. Den sluttede med starten på den globale økonomiske krise sidste år. Hvis Ukraine ikke bygger nye fabrikker, der kan producere konkurrencedygtige varer til verdensmarkedet, så har vi ingen fremtid".

Og kun 60 procent af det, som ukrainerne forbruger, er produceret i landet.

Ifølge Jatseniuk har Ukraine kun færdiggjort tre store byggeprojekter i de sidste 18 år: to atomkraftværker i Rivne og Khmelnitskij amterne og en motorvej fra Kijev til Odessa. "Det ved jeg, fordi vi betalte for projekterne, da jeg var fungerende leder af Ukraines Nationalbank", sagde han på vælgermødet.

Der mangler ifølge ukrainske øko- nomer reformer i alle samfundsmæssige sektorer fra industri- og landbrugsproduktion til uddannelse og sundhed. Det samme gælder i militæret, hvilket bekymrer mange, der ser den territoriale integritet truet af skærpede konflikter ned Rusland.

Da det hele ikke mindst handler om energi, er fraværet af en national politik og strategi for Ukraine som korridor for russisk energi til primært EU-lande særlig prekært.

Og i denne tid forudser det russiske gasmonopol Gasprom igen, at vi går en vinter i møde, hvor Ukraine ikke kan betale for leverancerne.

\section{Ny russisk offensiv}

Her mere end fem år efter at Ukraine fulgte revolutionsinspirationen fra Centraleuropa og skuede mod USA og Europa, søger Moskva et comeback for den russiske indflydelse i landet. Det ligner en åben dør, fordi den Orange Revolutions efterspil har været en ødelæggende magtkamp imellem revolutionens ledere, præsident Viktor Jusjtjenko og ministerpræsident Julia Tymosjenko. Den provestlige Jusjtjenko, der engang var revolutionshelt, kæmper nu med kun få procents opbakning i meningsmålinger op til præsidentvalget i januar. Tymosjenko står en del bedre, men Viktor Janukovitj , som Moskva støttede ved det svindelagtige præsidentvalg $\mathrm{i}$ 2004, fører nu i meningsmålingerne. 
Den russiske ledelse burde have lært af erfaringerne fra den Orange Revolution og holde sig i baggrunden denne gang. Men i stedet har Rusland i de seneste måneder intensiveret propagandaen om Ukraine som en fjendtlig nabo, så længe Jusjtjenko er ved magten. Forholdet imellem de to store slaviske naboer er det dårligste siden Sovjetunionens sammenbrud.

Det bekymrer internationalt, og mange ukrainske analytikere stiller spørgsmålet, om de russiske ledere forbereder en mere alvorlig konfrontation med Ukraine blot lidt over et år efter konfrontationen med Georgien.

"Krig og konflikter begynder med, at det diskuteres som en mulighed. For første gang i årevis bruges ordet 'krig' her, og det afvises ikke som en mulighed", siger Valaryj Tjalij, udenrigspolisk analytiker ved forskningsinstituttet Rasumkov Center i Kijev, til Washington Post.

Julia Mostovaja skriver i den uafhængige ukrainske avis Zerkalo Nedeli som hun er redaktør for, at Jusjtjenkos manglende evne til at videreføre demokratiske reformer efter den Orange Revolution "har efterladt Ukraine mere sårbart over for indflydelse fra Rusland".

Over 20 fremtrædende ukrainske politikere, forfattere og kunstnere advarede i et åbent brev den 10. september USA's præsident Barack Obama og andre vestlige ledere, at Rusland udgør en stadig større fare for Ukraine. De opfordrede vestlige ledere til at afholde en international konference med henblik på at give Ukraine sikkerhedsgarantier. Det hedder i brevet:

"Den russiske ledelse har bevidst valgt en kurs for at ødelægge eksisterende sikkerhedssystemer. Hovedformålet er at underkaste Ukraine Ruslands geopolitiske interesser. Der er tegn på, at Kreml ikke udelukker brugen af våbenarsenaler og militære metoder. Propagandakrigen imod Ukraine har nået hidtil usete niveauer. Der skabes et billede af Ukraine som fjende af det russiske samfund".

I brevet henvises til, at den russiske Duma kort forinden under sin førstebehandling havde godkendt en ny militærdoktrin, der sanktionerer brugen af de russiske militære styrker i udlandet.

Brevskriverne henviser også til $\mathrm{Bu}$ dapest Memorandum om Sikkerhedsgarantier, underskrevet 5 . december 1994 efter Ukraines beslutning om at overdrage sine atomarsenaler til Rusland. Ifølge gruppen bør EU, Storbritannien, Frankrig og Kina "optræde fast og utvetydigt for at sikre Ukraines suverænitet".

Blandt underskriverne er tidligere præsident Leonid Kravtjuk og forfatteren Jurij Andrukhovytj.

18 år efter Sovjetunionens sammenbrud har mange russere det stadig dårligt med Ukraines selvstændighed, og en stor minoritet i Ukraine - ikke kun russere - har stærke 
følelser for landets kulturelle og historiske bånd til Rusland.

Relationerne har altid været problematiske, men blev det især efter den Orange Revolution, hvor massedemonstrationer imod valgsvindel for Moskvas kandidat banede vejen for et provestligt styre.

Den demokratiske folkeopstand i Ukraine skabte frygt blandt Ruslands autoritære ledere for en 'farverevolution' også i deres land, og Ukraines efterfølgende bestræbelser for NATO-medlemskab skabte noget nær panik iblandt dem. Gensidige anklager imellem Moskva og Kijev blev nærmest rutine og har toppet med to bitre vinterkriser om Ruslands gasleverancer til og igennem Ukraine til Central- og Vesteuropa.

\section{Optrappet retorik}

Den russiske retorik er optrappet med anklager imod Ukraine for at sende tropper og våben til Georgien sidste år og for at true den russiske Sortehavsflåde i Sevastopol. Ruslands præsident, Dmitrij Medvedev, sendte noget nær en krigserklæring i et brev i august, hvor han fordømte sin ukrainske kollega.

Her opremser Medvedev en række 'anti-russiske' skridt fra Ukraine, herunder landets ønske om NATOmedlemskab, dårlig behandling af russiske investorer, restriktioner imod brug af det russiske sprog samt forsøg på at tolke historien, så Sovjetunionen begik folkemord imod ukrainere i 1930'erne. Det var hungerkatastrofen, holodomor på ukrainsk, som Ukraine forsøger at få anerkendt som folkemord.

I en dyster video, der blev offentliggjort sammen med brevet, og med krigsskibe i Sortehavet bag sig, sagde Medvedev, at han ville undlade at sende en ny ambassadør til Ukraine. Han sagde, at spændinger imellem de to lande har nået hidtil usete niveauer, og han opfordrer Ukraines kommende præsident til at være mere venlig.

Jusjtjenko svarede i et interview til Financial Times, hvor han anklager Rusland for at blande sig i Ukraines indre anliggender og siger, at "Rusland kører en smædekampagne for at manipulere ukrainske vælgere".

Jusjtjenko forventer, at Rusland oppisker separatistiske følelser på den russisk dominerede Krim Halvø. "De vil prøve at bruge 'Krim Kortet", siger Jusjtjenko, der dog ikke tror, at det kan udvikle sig til russisk militær indgriben som i Georgien. "Ukraine er ikke Georgien", siger Jusjtjenko. Det har han så ganske ret i med Ukraines langt større befolkning, langt stærkere hær og mere centrale geopolitiske placering i den nye øst-vest konflikt, der udspiller sig om især tidligere sovjetrepublikker tæt på EU.

"Der er en masse skjulte og kyniske spil, som føres gennem informationskanaler for at miskreditere Ukraine «", siger Jusjtjenko.

"Vi er grundlæggende gået ind i en 
kold krig", sagde Oleksandr Tretjakov, leder af Justjenkos partis parlamentsgruppe, til den britiske avis. Han mener, at Rusland prøver at bruge sine økonomiske muskler til at fremstille Ukraine som en 'fejlslagen stat' og søger at slå den Orange Revolution endelig tilbage. Den revolution har Moskva beskrevet som intet mere end et amerikansk støttet kup.

\section{Skyder sig selv i foden}

Ukrainske politikere er enige $i$, at der er en smædekampagne i gang, som russiske statsstyrede medier deltager meget aktivt i. Men ofte undres man over, at russerne farer så hårdt frem, når ukrainske ledere er så gode til at skyde sig selv $\mathrm{i}$ foden med interne slagsmål. På den baggrund ville russerne formentlig få mere ud af at læne sig tilbage og lade ukrainere selv sørge for at bringe næring til NATOs og EU's skepsis imod øget tilnærmelse.

Men propagandaen synes at virke og ses af mange uafhængige russiske kommentatorer som Kremls forsøg på at aflede befolkningens opmærksomhed fra de hjemlige problemer.

Meningsmålinger viser, at russerne er mere negative over for Ukraine end over for USA. Den hårde retorik synes derimod ifølge meningsmålinger ikke at have ødelagt de traditionelt varme følelser for russerne blandt ukrainere, selv de meget kritiske over for Kremls politik. Og mens ukrainere er et ubetydeligt mindretal i Rusland, udgør russere otte millioner af Ukraines 46 millioner med det store mindretal primært koncentreret i øst og syd.

Russiske ledere kalder en venligsindet regering i Ukraine for deres 'strategiske prioritet'. Ud over ledningsnettet, der bringer russisk gas til Europa, er lejekontrakten for den russiske Sortehavsflådes hovedbase i Sevastopol et hovedpunkt i konflikterne. Ruslands kontrakt med Ukraine udløber i 2017 og bliver ikke forlænget ifølge Ukraine. Det gør den, ifølge Rusland.

\section{Lille Rusland}

Ruslands ministerpræsident Vladimir Putin sagde engang til USA's tidligere præsident George W. Bush, at Ukraine ikke er et egentligt land. På en pressekonference i maj i år fulgte han den påstand op med oplæsning af dagbogsblade fra en general i tsartiden, der kaldte Ukraine 'lille Rusland'.

Dmitrij Trenin, direktør for Carnegie Center i Moskva, skriver på Carnegies hjemmeside, at Kreml ikke kan forestille sig Rusland som en stormagt uden Ukraine. Debatten blandt russiske politikere står ifølge Trenin imellem moderate, der vil forhindre Ukraine i at tilslutte sig NATO og sikre, at det fortsætter som transitland for russisk gas, og på den anden side politikere, der kræver en strategi for 'blød dominans' over naboen. 
Både Putin og Medvedev har personlig interesse $i$ at se den Orange Revolution rullet tilbage, da den ses som et ydmygende nederlag i Moskva. Putin anerkendte som præsident taberen som vinder ved det ukrainske valg i 2004, mens Medvedev havde ansvar for den massive russiske kampagne, der gav tilbageslag.

Mikhailo Pohrebinskij, politisk rådgiver for Ukraines tidligere præsident og samarbejdspartner for Medvedev, har udtalt, at Medvedev nu synes at opbygge en sag om, at Ukraine krænker venskabstraktaten med Rusland fra 1997, den eneste aftale, hvor Moskva har anerkendt Ukraines grænser.

Eskalering af konflikterne kom i usædvanligt svære tider for Ukraine, der er ramt ekstraordinært hårdt af den globale økonomiske krise og kæmper for at gennemføre de pinefulde reformer, som IMF kræver for milliarder i lån til at imødegå krisen. Op til præsidentvalget er den splittede ledelse om muligt endnu mere splittet, end den i tider uden valgkamp har været siden den Orange Revolution. Og IMF søges trukket ind i den bitre ukrainske rivalisering.

Jusjtjenko har anklaget IMF for at være for eftergivende over for regeringen, ledet af hans rival til præsidentposten, Tymosjenko. Ifølge Jusjtjenko må IMF være hårdere, når det gælder at kræve reformer som betingelse for udbetalinger af flere portioner af lånet, bevilget i december sidste år. "Hverken Verdensbanken eller IMF har gjort, hvad de skulle: presse regeringen til reformer", sagde Jusjtjenko 16. september ifølge Financial Times. Og præsidenten anklager også regeringen for populisme, da den vægrer sig ved at hæve gasprisen til markedsniveau for private ukrainske forbrugere.

På sin side anklager Tymosjenko præsidenten for at sabotere regeringens bestræbelser på at hale Ukraine ud af krisen. Og hun anklager Jusjtjenko, der udnævner ledelsen af nationalbanken, for at bruge banken imod regeringen i blandt andet spillet om den pressede valuta, hryvniaen.

Og mon ikke præsidentkandidat Viktor Janukovitj er henrykt for de to kamphaners gensidige anklager?

Rusland har ikke denne gang officielt støttet Janukovitj, leder af det største oppositionsparti, Regionernes Parti. Ifølge ukrainske kommentatorer har Janukovitj gjort store fremskridt i øvelsen at ryste det gamle image som korrupt bureaukrat af sig.

Selv om Janukovitj stadig måtte være Moskvas favoritkandidat, synes den russiske ledelse at sprede sine kort denne gang. Det er kun Jusjtjenko, som angribes personligt af russiske politikere og medier. Men igen behøver de næppe at gøre sig ulejligheden, da han fremstår som en så upopulær og ineffektiv leder, 
at han har ringe chance for at vinde. Oleksandr Susjko, forskningsdirektør ved Institute for Euro-Atlantic Cooperation i Kijev, mener, at Kreml prøver at mase sig ind på valgkampagnedagsordenen ved at kræve, at kandidaterne klargør deres holdning til emner i Ruslands interesse.

Men alle de vigtigste kandidater, herunder Janukovitj, er for mere integration i Europa og synes ikke parate til de mange indrømmelser, som Rusland kræver.

Janukovitjs stærkeste konkurrent er ministerpræsident Julia Tymosjenko, der vil forbedre relationerne til Rusland, men uden at give $\mathrm{k} ø \mathrm{~b}$ på Ukraines selvstændighed, siger hun.

Tymosjenko fik ros fra Putin, da hun indgik en aftale imellem dem, der afsluttede den seneste gaskonflikt. Men hun forpligtede Ukraine til at købe en bestemt mængde gas i en kontrakt, som hun nu forsøger at genforhandle.

\section{Gas og offermentalitet}

Tymosjenko og Putin kom ud fra et møde i august, hvor det forlød, at Rusland i princippet var indstillet på at give Ukraine et pusterum. Men siden er det blevet klart, at hun kan have efterladt sig selv åben for afpresning, måske lige før valget. Rusland har fx hidtil forhindret effektuering af en aftale, som Tymosjenko har underskrevet med EU, om hjælp fra unionen til at modernisere og reformere Ukraines gassektor.

Og Rusland er kategorisk imod, at EU køber gassen ved den ukrainskrussiske grænse, så Rusland fratages ansvar for transitten gennem Ukraine.

Der ligger en gammel diskussion bag. "Rusland har ingen ret til en indflydelsessfære i Østeuropa, og Vesten burde gøre det pinefuldt klart", skrev Kyiv Post i november 2004 og hævdede, at russiske soldater myldrede ind i Kijev i ukrainske uniformer. Og rygterne gik, at russiske fly landede i lokale lufthavne med soldater, der var parate til at nedkæmpe demonstranterne.

Lederen konkluderer: "Hvis Kreml nægter at opføre sig ordentligt, må Vesten tæmme Putins brutale revanchistiske ambitioner. Vestlige magter lod Østeuropa falde i Moskvas aggressive klør i 1945. Det bør de ikke gøre igen".

I den aktuelle debat blandt ukrainerne er den 'offermentalitet' tydelig, som journalisten Natalija Bugajova her indledningsvis er citeret for at pege på. Ukrainere føler sig svigtet af Vesten og delvist med god grund. NATO har ret $\mathrm{i}$, at landet ikke er parat til medlemskab, men argumenter imod at gå i den retning, som ikke mindst Tyskland er i spidsen for, er drevet af Ruslands hårde modstand.

EU har også ret i, at medlemskab af den klub kræver meget mere, end Ukraine nu kan levere. Men at stille medlemskab i udsigt, når betingel- 
serne er opfyldt, kunne givetvis have hjulpet Ukraine meget. Når EU ikke har givet et så uforpligtende løfte, er hensynet til Rusland uden tvivl den væsentligste grund.

"Den Orange Revolution var mit livs bedste oplevelse. Dengang var vi her for at hylde politikere på denne plads. Nu er jeg her bare for at nyde koncerten”, sagde den 28-årige kontorarbejder Oleksandra til Kyiv Post under et valgmøde på Frihedspladsen i Kijev. Hun ville ikke opgive sit navn til den ukrainske avis, fordi hun var bange for at blive til grin på arbejdet. Der var primært unge ved det valgmøde, fordi nogle af Ukraines bedste rockgrupper optrådte. Den 60-årige Lubov Lasarenko kiggede på fra afstand og sagde: "Berømtheder er som regel til salg. Dette er en lille replika af Ukraine, hvor en håndfuld rige optræder for de fattige masser". Lasarenko stemte på Janukovitj i 2004, men nu aner han ikke, hvem han skal stemme på i januar.

Umiddelbart er den bedste hjælp, som Ukraine kan ydes udefra, nok mere international fokus på opløbet til valget i januar. Og IMF bør på den ene side fastholde kravene om reformer, men også vise en høj grad af fleksibilitet. Det forholder sig nemlig sådan, for nu at slutte positivt, at Ukraines økonomi i den sidste tid har vist tegn på at komme på fode igen.

Det indenrigspolitiske kaos støtter på farlig vis Ruslands muligheder for at blande sig. Og det store spørgsmål er, om der er nok almindelige ukrainere, som står parat til at sige nej, som tilfældet var under den Orange Revolution.

Vibeke Sperling er Østeuropakorrespondent ved dagbladet Politiken. 